\title{
Perubahan Perilaku Aparatur sebagai Model dalam Mewujudkan Reformasi Birokrasi yang Berkualitas
}

\author{
Henny Juliani \\ Fakultas Hukum Universitas Diponegoro \\ hennyjuliani.fhundip@gmail.com
}

\begin{abstract}
This research was conducted to find out changes of Public Servants mental and behavior as a model in creating qualified bureaucracy reformation as concequence of negative issues on Public Servants professionalism, particularly on their quality and performance. This research used normative juridical method by using analytical descritive approach. The Government took strategic action in developing human resources of Public Servant through bureaucracy reformation policy focused on changing Public Servants mental and behavior. The change is intended not only for Public Servants, but also for all related system. The focus of the change of bureaucration is expected will create clean and accountable, effective, efficient bureaucationand able to provide qualified public service as well.
\end{abstract}

Keywords: behavior of Public Servants, bureaucration reformation

\begin{abstract}
Abstrak
Penelitian ini dilakukan untuk mengetahui perubahan mental/perilaku aparatur sebagai model dalam mewujudkan reformasi birokrasi yang berkualitas sebagai akibat dari isu negatif terhadap profesionalisme khususnya pada aspek kualitas dan kinerja ASN. Metode pendekatan yang digunakan adalah yuridis empiris, spesifikasi penelitian yang digunakan adalah deskriptif analitis. Pemerintah mengambil langkah strategis membangun SDM aparatur melalui kebijakan reformasi birokrasi dengan inti perubahan pada mental/perilaku aparatur. Perubahan tersebut selain ditujukan langsung kepada aparatur, juga harus ditujukan kepada seluruh sistem yang melingkup aparatur. Fokus perubahan reformasi birokrasi tersebut diharapkan dapat menciptakan birokrasi yang bersih dan akuntabel, efektif, efisien, serta mampu memberikan pelayanan publik yang berkualitas.
\end{abstract}

Kata kunci: Mental/perilaku aparatur, reformasi birokrasi

\section{A. Pendahuluan}

Dalam rangka mewujudkan tujuan nasional negara Kesatuan Republik Indonesia dibutuhkan pegawai Aparatur Sipil Negara (ASN) yang profesional, bebas dari intervensi politik, bersih dari praktik korupsi, 
kolusi, dan nepotisme, mampu menyelenggarakan pelayanan publik dan menjalankan peran sebagai perekat persatuan dan kesatuan bangsa berdasarkan Pancasila dan UUD Tahun 1945. Sayangnya, tingkat kepuasan masyarakat sebagai pengguna pelayanan masih rendah. Selain masih banyaknya keluhan masyarakat, profesionalitas SDM aparatur sebagai penyedia layanan juga masih dipertanyakan. Masih terdapat pelanggaran yang sering dilakukan ASN dalam melaksanakan tugasnya.

Masalah integritas ASN dapat dilihat dari banyaknya perilaku menyimpang yang dilakukan oleh para pegawai ASN seperti Korupsi, Kolusi dan Nepotisme (KKN). Masalah kompetensi dapat dilihat dari tingkat pendidikan mayoritas pegawai ASN yang masih rendah, menurut Menpan RB dari 4.475.997 PNS ASN $64 \%$ di antaranya hanya bekerja sebagai petugas administrasi. Masalah kinerja ASN dapat dilihat dari output dimana masih banyak dikeluhkan masyarakat atas lambatnya pelayanan publik. Masalah disiplin dapat dilihat dari masih adanya perbuatan pegawai ASN yang melanggar peraturan dan ketentuan yang ada seperti netralitas PNS, yaitu adanya dugaan keterlibatan pegawai ASN dalam kampanye Calon Gubernur dan Calon Wakil Gubernur Provinsi Banten tahun 2017. ${ }^{1}$

Temuan Indonesian Corruption Watch menempatkan aparatur sipil negara sebagai aktor yang paling banyak terjerat kasus korupsi pada 20102016. Setidaknya sekitar 3.417 aparatur sipil negara (ASN) ditetapkan sebagai tersangka kasus korupsi di sejumlah daerah. ${ }^{2}$

Data tersebut menunjukkan bahwa profesionalitas SDM aparatur dalam menyelenggarakan pelayanan masih belum terwujud. Oleh karena itu diperlukan langkah strategis membangun SDM aparatur melalui kebijakan reformasi birokrasi agar tata kelola pemerintahan yang baik

1 Ajib Rakhmawanto, Mengukur Indeks Profesionalitas ASN: Analisis Tujuan dan Kemanfaatan, Jurnal Policy Brief Nomor: 006-April 2017 ISSN: 2541-4267.

2 Krisiandi, Kegagalan Reformasi Birokrasi,

https://nasional.kompas.com/read/2017/04/07/17595581/kegagalan.reformasi.birokrasi. Diunduh pada tanggal 17 April 2018 pukul 22.07 WIB 
(good governance) dapat terwujud dan masyarakat yang dilayani dapat merasakan dampak perubahan yang lebih baik.

Berdasarkan hal-hal tersebut di atas, maka penelitian ini dilakukan untuk mengetahui perubahan mental/perilaku aparatur sebagai model dalam mewujudkan reformasi birokrasi yang berkualitas sehingga dapat menunjang pelaksanaan pelayanan publik yang lebih baik dan memuaskan masyarakat.

\section{Metode Penelitian}

Metode pendekatan dalam penelitian ini menggunakan pendekatan yuridis empiris yang berhubungan erat dengan law in action. Spesifikasi penelitian yang digunakan adalah deskriptif analitis, dan selanjutnya dilakukan analisa secara kualitatif. Penelitian ini menggunakan data primer dan data sekunder. Ronny Hanityo Soemitro menyatakan bahwa data sekunder dalam penelitian hukum dapat dibagi kembali berdasarkan kekuatan mengikatnya, ${ }^{3}$ dapat dibedakan menjadi bahan-bahan hukum primer, bahan-bahan hukum sekunder dan bahan-bahan hukum tersier.

\section{- Kerangka Teori}

Berdasarkan ketentuan Pasal 1 ayat (3) UUD 1945, "Negara Indonesia adalah negara hukum." Sebagai negara hukum, maka setiap penyelenggaraan urusan pemerintahan haruslah berdasarkan pada hukum yang berlaku. Sehingga dapat dikatakan bahwa dalam suatu negara hukum, semua harus tunduk kepada hukum secara sama, yakni tunduk kepada hukum yang adil. Tidak ada seorangpun termasuk penguasa negara yang kebal terhadap hukum ${ }^{4}$.

Menurut Hamid S. Attamimi, bahwa negara Indonesia sejak didirikan memang bertekad menetapkan dirinya sebagai negara yang berdasar atas hukum, sebagai rechtsstaat. Bahkan rechtsstaat Indonesia itu ialah rechtsstaat yang "memajukan kesejahteraan umum", "mencerdaskan

3 Ronny Hanityo Soemitro, Metodologi Penelitian Hukum dan Yurimetri, (Jakarta: Ghalia Indonesia, 1994), halaman 11-12

4 Munir Fuadi, Teori Negara Hukum Modern (Rechtstaat), (Bandung: P.T. Refika Aditama, 2009), halaman 2. 
kehidupan bangsa", dan "mewujudkan suatu keadilan sosial bagi seluruh rakyat Indonesia. Rechtsstaat itu ialah rechtsstaat yang materiil, yang sosial, yang oleh bung Hatta disebut Negara Pengurus, suatu terjemahan Verzorgingsstaat. ${ }^{5}$ Untuk mewujudkan tujuan nasional tersebut, maka dibutuhkan birokrasi/pegawai ASN yang diberi tugas untuk melaksanakan tugas pelayanan publik, tugas pemerintahan, dan tugas pembangunan tertentu.

Birokrasi adalah kata yang lekat dengan mesin kerja pemerintah. Meskipun sesungguhnya birokrasi adalah salah satu tipe organisasi, akan tetapi secara awam lebih merefleksikan organisasi pemerintah. Di Indonesia jumlah birokrat sebanyak 4,7 juta memang belum memadai atau sebanding dengan jumlah masyarakat yang dilayani yang mencapai angka 270 jutaan penduduk. $^{6}$

Menurut Peter M. Blau dan Marshall W. Meyer, "Birokrasi" dalam pengertian sehari-harinya diidentikkan dengan ketidakefisienan (inefficiency) atau "benang merah" dalam pemerintahan; arti yang sebenarnya tidaklah demikian. ${ }^{7}$

Organisasi pemerintah layaknya organisasi pada umumnya menuntut adanya profesionalisme ASN sebagai kunci keberhasilan bagi proses penyelenggaraan pelayanan publik. Oleh karena itu profesionalitas pegawai ASN perlu dikembangkan dan menjadi perhatian khusus bagi pemerintah. Isu negatif terhadap profesionalisme khususnya pada aspek kualitas dan kinerja ASN perlu direspon positif dengan melakukan evaluasi. Publik memandang pada umumnya problem profesionalisme ASN dapat dilihat dari kurangnya integritas, rendahnya kompetensi, lambatnya kinerja, dan banyaknya pelanggaran disiplin. ${ }^{8}$ Hal tersebut

Ibid, halaman 18

6 Kristian Widya Wicaksono, Telaah Kritis Administrasi \& Manajemen Sektor Publik di Indonesia, (Yogyakarta: Penerbit Gava Media, 2014), halaman 51

7 Peter M. Blau dan Marshall W. Meyer, diterjemahkan oleh Gary R. Jusuf, Birokrasi dalam Masyarakat Modern, (Jakarta: UI Press, tanpa tahun), halaman 3-4

Ajib Rakhmawanto, Op cit, halaman 1. 
menuntut diberlakukannya reformasi birokrasi, khususnya terhadap mental/perilaku aparatur.

Kebijakan reformasi birokrasi dalam mengelola sumber daya aparatur dapat dilakukan dengan tahapan sebagai berikut: ${ }^{9}$

1. Menata dan reformasi organisasi, yaitu redefinisi Visi, Misi, Tata Laksana (proses bisnis).

2. Menyusun direktori kompetensi didasarkan pada tugas dan fungsi organisasi atau lembaga.

3. Menyusun Standar Kebutuhan Kompetensi Jabatan.

4. Melakukan Penilaian Kompetensi Pegawai.

5. Penggunaan hasil pengukuran kompetensi jabatan dan penilaian kompetensi pegawai dalam melaksanakan fungsi-fungsi manajemen kepegawaian seperti pengadaan pegawai, penilaian kinerja, perencanaan karir, penempatan, pelatihan, pemberian insentif, dan sebagainya.

\section{B. Pembahasan}

Sebagaimana diketahui bahwa birokrasi adalah merupakan jenis organisasi yang dirancang untuk menangani tugas-tugas administratif dalam skala besar serta mengkoordinasikan pekerjaan orang banyak secara sistematis. Birokrasi dapat dikatakan sebagai “mesin kerja pemerintah.” Posisi birokrasi yang sangat penting tersebut menjadikan birokrasi disorot dalam kinerjanya dan dituntut profesional dalam mewujudkan keberhasilan bagi proses penyelenggaraan pelayanan publik. Oleh karena itu maka berdasarkan Peraturan Presiden Nomor 81 Tahun 2010 tentang Grand Design Reformasi Birokrasi 2010-2025 dan Peraturan Menpan RB Nomor 11 Tahun 2015 tentang Road Map Reformasi Birokrasi 2015-2019 serta peraturan pelaksana lainnya, pemerintah berusaha menjawab permasalahan pemerintahan belum bersih, kurang akuntabel dan berkinerja rendah; pemerintahan belum efektif dan efisien; pelayanan publik masih buruk dengan mewujudkan pemerintahan

9 Dyah Kusumastuti, , https://www.researchgate.net/publication/316274009 Manajemen Sumber Daya Aparatur berbasis Kompetensi 
yang bersih, akuntabel dan berkinerja tinggi; pemerintahan yang efektif dan efisien; pelayanan publik yang baik dan berkualitas. Hal tersebut ditegaskan dalam sasaran Reformasi Birokrasi 2015-2019, bahwa:

1. Birokrasi yang bersih dan akuntabel

2. Birokrasi yang efektif dan efisien

3. Birokrasi yang memiliki pelayanan publik yang berkualitas.

Untuk mewujudkan ketiga sasaran reformasi birokrasi sebagaimana disebutkan di atas, ditetapkan area-area perubahan birokrasi. Perubahanperubahan pada area tertentu dalam lingkup birokrasi diharapkan menciptakan kondisi yang kondusif untuk mendukung pencapaian tiga sasaran reformasi birokrasi. Area-area perubahan tersebut adalah:

\section{Mental Aparatur}

Permasalahan utama birokrasi adalah perilaku negatif yang dilakukan oleh para birokrat, yang mendorong terciptanya citra negatif birokrasi. Perilaku mental model birokrasi yang dipandang lambat, berbelit-belit, tidak inovatif, tidak peka, inkonsisten, malas, feodal, dan lainnya. Oleh karena itu, fokus perubahan reformasi birokrasi ditujukan pada perubahan mental aparatur. Perubahan ini diharapkan akan mendorong terciptanya budaya kerja positif yang kondusif untuk menciptakan birokrasi yang bersih dan akuntabel, efektif, dan efisien serta mampu memberikan pelayanan yang berkualitas.

\section{Pengawasan}

Lemahnya sistem pengawasan menjadi penyebab timbulnya penyimpangan dalam birokrasi, yang mendorong tumbuhnya perilaku koruptif atau perilaku negatif lainnya yang semakin lama semakin menjadi, sehingga berubah menjadi sebuah kebiasaan. Oleh karena itu maka perubahan perilaku koruptif aparatur harus pula diarahkan melalui perubahan atau penguatan sistem pengawasan.

\section{Akuntabilitas}

Pemerintah dipandang belum mampu menunjukkan kinerja dan mempertanggungjawabkannya melalui pelaksanaan kegiatan-kegiatan yang mampu menghasilkan outcome (hasil yang bermanfaat) bagi 
masyarakat. Oleh karena itu, penerapan sistem akuntabilitas perlu diperkuat sehingga dapat mendorong birokrasi lebih berkinerja dan mampu mempertanggungjawabkan kinerjanya sesuai dengan segala sumber-sumber yang dipergunakannya.

\section{Kelembagaan}

Struktur yang terlalu gemuk dan memiliki banyak hirarki pada kelembagaan pemerintah menyebabkan timbulnya proses yang berbelit, kelambatan pelayanan dan pengambilan keputusan, dan akhirnya menciptakan budaya feodal pada aparatur sehingga tidak efektif dan efisien. Oleh karena itu, perubahan pada sistem kelembagaan akan mendorong efisiensi, efektivitas, dan percepatan proses pelayanan dan pengambilan keputusan dalam birokrasi. Hal tersebut diharapkan akan dapat mendorong terciptanya budaya/perilaku yang lebih kondusif untuk mewujudkan birokrasi yang efektif dan efisien.

\section{Tatalaksana}

Proses bisnis/tatakerja/tatalaksana yang tidak jelas dalam instansi pemerintah juga sering menjadi kendala penyelenggaraan pemerintahan sehingga tidak ada kepastian waktu. Hal tersebut kemudian mendorong terciptanya perilaku hirarkis, feodal, dan kurang kreatif pada birokrat/aparatur. Oleh karena itu, diperlukan perubahan pada sistem tatalaksana untuk mendorong efisiensi penyelenggaraan pemerintahan dan pelayanan, sekaligus juga untuk mengubah mental/perilaku aparatur.

\section{SDM Aparatur}

Sistem manajemen SDM aparatur yang diterapkan pada setiap instansi dan secara nasional dapat berpengaruh pada perilaku aparaturnya. Sistem manajemen SDM yang tidak diterapkan dengan baik mulai dari perencanaan pegawai, pengadaan, hingga pemberhentian dapat berpotensi menghasilkan SDM yang tidak kompeten sehingga akan berpengaruh pada kualitas penyelenggaraan pemerintahan dan pelayanan. Oleh karena itu, perubahan dalam manajemen SDM harus selalu dilakukan untuk memperoleh sistem manajemen SDM yang mampu menghasilkan pegawai yang profesional. 


\section{Peraturan Perundang-undangan}

Faktor penyebab munculnya perilaku negatif aparatur lainnya adalah peraturan perundang-undangan yang tumpang tindih, disharmonis, dapat diinterpretasi berbeda atau sengaja dibuat tidak jelas untuk membuka kemungkinan penyimpangan, yang seringkali dimanfaatkan oleh aparatur untuk kepentingan pribadi yang dapat merugikan negara. Oleh karena itu, perlu dilakukan perubahan/penguatan terhadap sistem peraturan perundang-undangan yang lebih efektif dan memenuhi kebutuhan masyarakat.

\section{Pelayanan Publik}

Pelayanan publik aparatur seringkali menjadi sorotan masyarakat. Penerapan sistem manajemen pelayanan belum sepenuhnya mampu mendorong peningkatan kualitas pelayanan, yang lebih cepat, murah, berkekuatan hukum, nyaman, aman, jelas, dan terjangkau serta menjaga profesionalisme para petugas pelayanan. Oleh karena itu, perlu penguatan terhadap sistem manajemen pelayanan publik agar mampu mendorong profesionalisme para penyedia pelayanan serta peningkatkan kualitas pelayanan. Inti perubahan dari reformasi birokrasi adalah perubahan pada mental aparatur, namun perubahan tersebut ditujukan kepada seluruh sistem yang melingkup aparatur tidak hanya kepada aparaturnya saja. Keterkaitan antara area perubahan dan sasaran reformasi birokrasi dapat dilihat pada gambar di bawah ini: 


\section{Gambar 1}

\section{Area Perubahan dan Sasaran Reformasi Birokrasi}

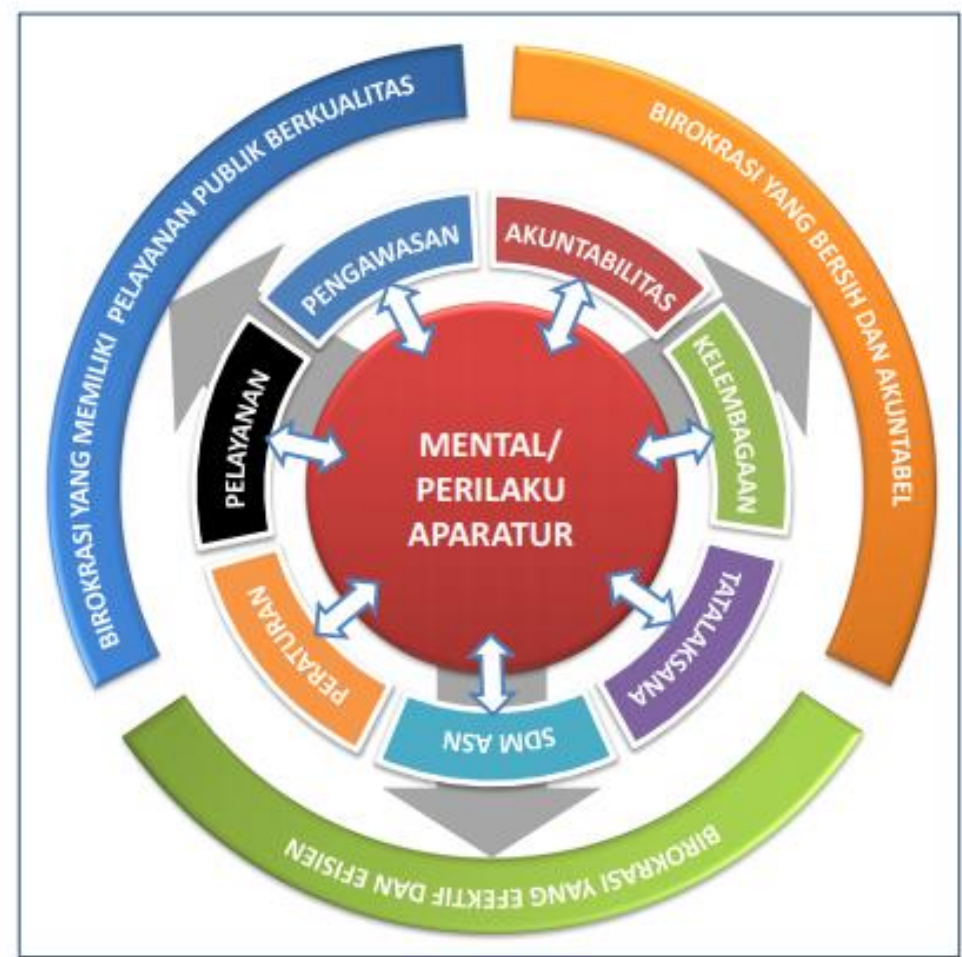

Sumber : KemenPAN dan RB

Inti perubahan dari reformasi birokrasi adalah perubahan pada mental/perilaku aparatur. Perubahan tersebut tidak dapat dilakukan hanya melalui langkah-langkah yang ditujukan langsung kepada aparatur, tetapi juga harus ditujukan kepada seluruh sistem yang melingkup aparatur.

Hasil yang diharapkan dari perubahan pada area-area dimaksud di atas dituangkan dalam Tabel sebagai berikut:

\section{Tabel . Area Perubahan Dan Hasil Yang Diharapkan}

\begin{tabular}{|c|c|}
\hline Area Perubahan & Hasil yang diharapkan \\
\hline $\begin{array}{ll}\text { 1. } & \text { Mental } \\
\text { Aparatur }\end{array}$ & 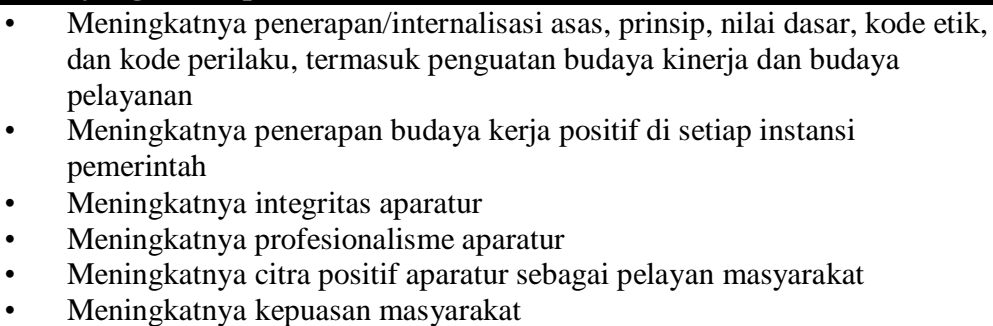 \\
\hline 2. $\quad$ Pen & $\begin{array}{ll}\text { - } & \text { Meningkatnya kapasitas APIP } \\
& \text { Meningkatnya penerapan sistem pengawasan yang independen, }\end{array}$ \\
\hline
\end{tabular}




\begin{tabular}{|c|c|}
\hline & $\begin{array}{ll} & \text { profesional, dan sinergis } \\
\text { - } & \text { Meningkatnya penerapan penyelenggaraan pemerintahan yang bersih dan } \\
\text { bebas KKN } \\
\text { - } & \text { Meningkatnya efisiensi penyelenggaraan birokrasi } \\
\text { - } & \text { Menurunnya tingkat penyimpangan oleh aparatur } \\
\text { - Meningkatnya jumlah instansi pemerintah yang memperoleh opini WTP } \\
\text { - BPK }\end{array}$ \\
\hline 3. Akuntabilitas & $\begin{array}{ll}\text { - } & \text { Meningkatnya kualitas penerapan sistem akuntabilitas keuangan dan } \\
\text { kinerja yang terintegrasi } \\
\text { - } \\
\text { Meningkatnya kualitas penerapan sistem pengadaan barang dan jasa yang } \\
\text { adil, transparan, dan profesional } \\
\text { - } \quad \text { Meningkatnya penerapan sistem manajemen kinerja nasional } \\
\text { Meningkatnya akuntabilitas aparatur }\end{array}$ \\
\hline 4. Kelembagaan & $\begin{array}{l}\text { - } \quad \text { Meningkatnya kualitas pelaksanaan agenda reformasi birokrasi nasional; } \\
\text { Meningkatnya ketepatan ukuran, ketepatan fungsi dan } \\
\text { sinergisme/kesinergisan kelembagaan Kementerian/lembaga pemerintah } \\
\text { non kementerian/lembaga non struktural; } \\
\text { Menurunnya tumpang tindih tugas dan fungsi antar } \\
\text { Kementerian/Lembaga dan antar Kementerian/Lembaga dengan } \\
\text { Pemerintah daerah; } \\
\text { Meningkatnya kejelasan pembagian kewenangan antara pemerintah } \\
\text { - } \quad \text { Meningkatnya sinergisme kelembagaan antara instansi pemerintah pusat } \\
\text { dan daerah; } \\
\text { - Meningkatnya sinergisme dan penguatan kelembagaan pada masing- } \\
\text { masing bidang pembangunan; } \\
\text { Meningkatnya kinerja aparatur }\end{array}$ \\
\hline 5. Tatalaksana & 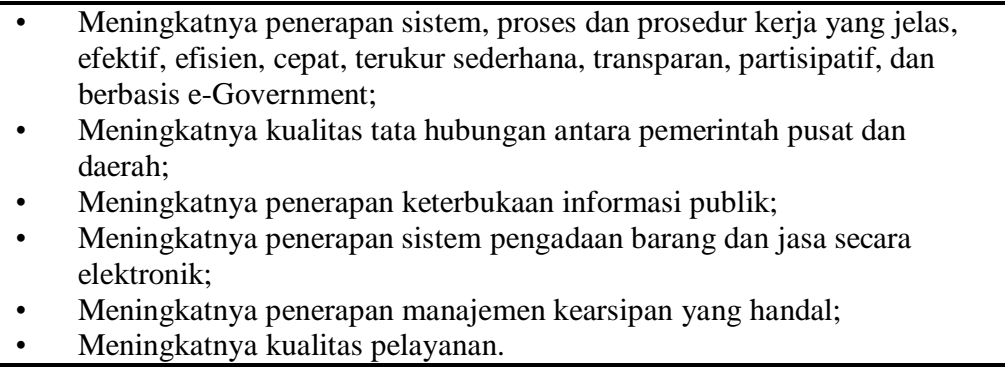 \\
\hline $\begin{array}{l}\text { 6. Sumber daya } \\
\text { manusia } \\
\text { aparatur } \\
\text { sipil negara }\end{array}$ & $\begin{array}{l}\text { - Meningkatnya kemampuan unit yang mengelola SDM ASN untuk } \\
\text { mewujudkan SDM aparatur yang kompeten dan kompetitif. } \\
\text { Meningkatnya kepatuhan instansi untuk penerapan manajemen SDM } \\
\text { aparatur yang berbasis merit; } \\
\text { Meningkatnya jumlah instansi yang mampu menerapkan manajemen } \\
\text { kinerja individu untuk mengidentifikasi dan meningkatkan kompetensi } \\
\text { SDM aparatur; } \\
\text { Meningkatnya jumlah instansi untuk membentuk talent pool (kelompok } \\
\text { suksesi) untuk pengembangan karier pegawai di lingkungannya; } \\
\text { - Meningkatnya jumlah instansi yang mampu mewujudkan sistem } \\
\text { informasi manajemen SDM yang terintegrasi di lingkungannya; } \\
\text { - Meningkatnya penerapan sistem pengembangan kepemimpinan untuk } \\
\text { perubahan; } \\
\text { Meningkatnya pengendalian penerapan sistem merit dalam Manajamen } \\
\text { - SDM aparatur; } \\
\text { Meningkatnya profesionalisme aparatur. }\end{array}$ \\
\hline $\begin{array}{l}\text { 7. } \begin{array}{l}\text { Peraturan } \\
\text { Perundang- } \\
\text { undangan }\end{array} \\
\end{array}$ & $\begin{array}{l}\text { - } \quad \text { Meningkatnya keterlibatan publik dalam proses perumusan kebijakan; } \\
\text { Meningkatnya kualitas regulasi yang melindungi, berpihak pada publik, } \\
\text { harmonis, tidak tumpang tindih dan mendorong iklim kondusif bagi } \\
\text { publik. }\end{array}$ \\
\hline $\begin{array}{ll}\text { 8. } & \begin{array}{l}\text { Pelayanan } \\
\text { publik }\end{array}\end{array}$ & 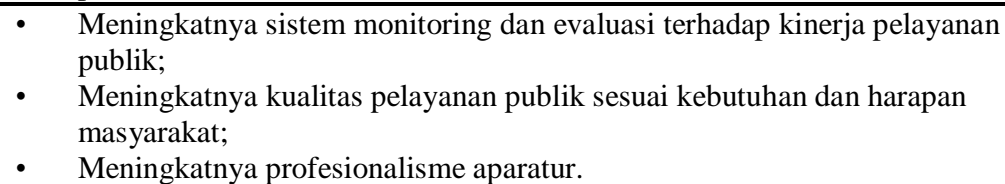 \\
\hline
\end{tabular}

Sumber: KemenPAN dan RB 
Menurut Pasal 25 ayat (1) Undang-Undang Nomor 5 Tahun 2014 tentang Aparatur Sipil Negara, Presiden selaku pemegang kekuasaan pemerintahan merupakan pemegang kekuasaan tertinggi dalam kebijakan, pembinaan profesi, dan manajemen ASN. Selanjutnya dalam Pasal 25 ayat (2) huruf a dinyatakan bahwa untuk menyelenggarakan kekuasaan sebagaimana dimaksud pada ayat (1), Presiden mendelegasikan sebagian kekuasaannya kepada Kementerian yang menyelenggarakan urusan pemerintahan di bidang pendayagunaan aparatur negara (Kemenpan RB), berkaitan dengan kewenangan perumusan dan penetapan kebijakan, koordinasi dan sinkronisasi kebijakan, serta pengawasan atas pelaksanaan kebijakan ASN. Pendelegasian sebagian kekuasaan Presiden juga diberikan kepada Badan Kepegawaian Negara (BKN) berkaitan dengan kewenangan penyelenggaraan manajemen ASN, pengawasan dan pengendalian pelaksanaan norma, standar, prosedur, dan kriteria manajemen ASN (Pasal 25 ayat (2) huruf d). Selain kedua lembaga tersebut, maka Presiden juga mendelegasikan sebagian kewenangannya kepada Komisi Aparatur Sipil Negara (KASN) sebagaimana diatur dalam Pasal 25 ayat (2) huruf b, dan Lembaga Administrasi Negara (LAN), yang diatur dalam Pasal 25 ayat (2) huruf c.

Reformasi birokrasi pada hakikatnya merupakan upaya untuk melakukan pembaruan dan perubahan mendasar terhadap sistem penyelenggaraan pemerintahan terutama menyangkut aspek-aspek kelembagaan (organisasi), ketatalaksanaan (business prosess) dan sumberdaya manusia aparatur, sehingga dapat menciptakan pemerintahan yang bersih dari KKN, akuntabel dan berkinerja, serta memiliki pelayanan publik yang berkualitas.

Menurut Adi Junjunan, strategi yang digunakan KemenPan dan RB dalam meningkatkan akuntabilitas pegawai adalah perlu dilakukan pembinaan integritas dan disiplin, terutama bekerjasama dengan Komisi Pemberantasan Korupsi (KPK) untuk pengisian LHKPN. Di sisi lain perlu dilakukan tindak lanjut Peraturan Pemerintah Nomor 42 Tahun 2004 
tentang Pembinaan Jiwa Korp dan Kode Etik PNS sebagai pedoman utama dalam mewujudkan akuntabilitas pegawai pada masing-masing instansi. Peraturan Pemerintah Nomor 53 Tahun 2010 juga menjadi acuan disiplin PNS, demikian pula akuntabilitas organisasi (berkaitan dengan sistem akuntabilitas kinerja instansi Pemerintah) maupun akuntabilitas individu harus mengacu pada Peraturan Pemerintah Nomor 46 Tahun 2011 maupun Peraturan Pemerintah Nomor 11 Tahun 2017. Dalam hal peningkatan pelayanan publik, harus berpedoman pada Undang-Undang 25 Tahun 2009 tentang Pelayanan Publik. ${ }^{10}$

Dalam meningkatkan kualitas pelayanan publik sesuai kebutuhan dan harapan masyarakat, maka instansi pemerintah sebagai penyelenggara pelayanan harus berpedoman pada Undang-Undang Nomor 25 Tahun 2009 tentang Pelayanan Publik. Menurut Pasal 2 Undang-Undang Pelayanan Publik dimaksudkan untuk memberikan kepastian hukum dalam hubungan antara masyarakat dan penyelenggara dalam pelayanan publik. Sebagai tindak lanjut pelaksanaan Undang-Undang tentang Pelayanan Publik maka dikeluarkan PerMenPan dan RB Nomor 14 Tahun 2017 tentang Pedoman Penyusunan Survey Kepuasan Masyarakat Unit Penyelenggara Pelayanan Publik, dan PerMenPan dan RB Nomor 16 Tahun 2017 tentang Pedoman Penyelenggaraan Forum Konsultasi Publik di Lingkungan Unit Penyelenggara Pelayanan Publik.

\section{Simpulan}

Berdasarkan hasil penelitian yang telah dilakukan, maka dapat disimpulkan bahwa permasalahan utama birokrasi adalah perilaku negatif yang dilakukan oleh para birokrat, sehingga mendorong terciptanya citra negatif birokrasi. Mental/perilaku model birokrasi tersebut dipandang lambat, berbelit-belit, tidak inovatif, tidak peka, inkonsisten, malas, feodal, dan lainnya. Oleh karena itu, fokus perubahan reformasi birokrasi ditujukan pada

10 Adi Junjunan, wawancara, Kepala Bagian Perencanaan Kinerja dan Anggaran KemenPan dan RB, Rabu 31 Oktober 2018 . 
perubahan mental/perilaku aparatur. Perubahan ini diharapkan akan mendorong terciptanya budaya kerja positif yang kondusif untuk menciptakan birokrasi yang bersih dan akuntabel, efektif, dan efisien serta mampu memberikan pelayanan yang berkualitas.

\section{Daftar Pusataka}

Blau, Peter M. dan Meyer, Marshall W., (tanpa tahun) diterjemahkan oleh Gary R. Jusuf, Birokrasi dalam Masyarakat Modern, (Jakarta: UI Press)

Fuadi, Munir, 2009, Teori Negara Hukum Modern (Rechtstaat), (Bandung: P.T. Refika Aditama)

Soemitro, Ronny Hanityo, 1994, Metodologi Penelitian Hukum dan Yurimetri, (Jakarta: Ghalia lndonesia)

Wicaksono, Kristian Widya, 2014, Telaah Kritis Administrasi \& Manajemen Sektor Publik di Indonesia, (Yogyakarta: Penerbit Gava Media)

Kusumastuti, Dyah, https://www.researchgate.net/publication/316274009 Manajemen Sumber Daya Aparatur berbasis Kompetensi

Rakhmawanto, Ajib, Mengukur Indeks Profesionalitas ASN: Analisis Tujuan dan Kemanfaatan, Jurnal Policy Brief Nomor: 006-April 2017 ISSN: 2541-4267.

Krisiandi, Kegagalan Reformasi Birokrasi, https://nasional.kompas.com/ read/2017/04/07/ 17595581/kegagalan.reformasi.birokrasi. Diunduh pada tanggal 17 April 2018 pukul 22.07 WIB 